\title{
A successful case of surgical intervention for traumatic globe luxation in a child: From light perception to full visual acuity
}

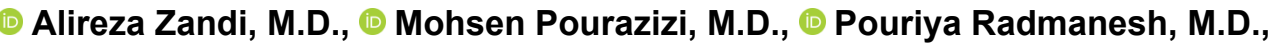 \\ Mohammad Hasan Alemzadeh Ansari, M.D.
}

Department of Ophthalmology, Isfahan Eye Research Center, Isfahan University of Medical Sciences, Isfahan-Iran

\begin{abstract}
Traumatic globe luxation is a rare condition in pediatric emergency medicine and can cause vision loss in some cases. Therefore, it is considered a critical condition in emergency rooms, and all physicians, particularly those working in emergency units, should be familiar with this condition and its management to be able to prevent organ-threatening complications, such as vision loss. This study reports the case of an 8-year-old girl with traumatic globe luxation due to falling from her bicycle. Her visual acuity (VA) decreased light perception. The condition was promptly managed with urgent lateral canthotomy and inferior cantholysis. At the one-month post-trauma follow-up, VA was 20/20 on the Snellen chart; no limitations in eye movement in any position of gaze were noted.
\end{abstract}

Keywords: Canthotomy; globe luxation; pediatric; trauma.

\section{INTRODUCTION}

Traumatic globe luxation is a rare condition in pediatric emergency medicine. It frequently occurs after a high-energy trauma to the orbito-facial area, mostly due to traffic accidents. ${ }^{[1,2]}$ Because traumatic globe luxation can lead to vision loss in some cases, it is an important condition in emergency rooms. ${ }^{[3]}$ Hence, all physicians, particularly those working at emergency units, should be familiar with this condition and its management to be able to prevent organ-threatening complications, such as vision loss.

This study reports the case of an 8-year-old girl with traumatic globe luxation due to falling from her bicycle; her visual acuity reduced to light perception. The condition was immediately managed with urgent lateral canthotomy and inferior cantholysis. At the one-month post-trauma follow-up, VA was 20/20 on the Snellen chart and no limitations in eye movement in any position of gaze were noted.

\section{CASE REPORT}

An 8-year-old girl was admitted to the emergency department of our hospital after falling from her bicycle. Her left eye had suffered trauma caused by the bicycle brake handle I hour prior to admission. Ophthalmological examination revealed superior eyelid laceration and intact globe luxation out of the orbit in the anterior direction with the posterior part of the globe tightly held between the eyelids (Fig. Ia). Visual Acuity (VA) was reduced to light perception. A positive relative afferent pupillary defect was observed in the left eye. Left ocular motility was severely limited in all positions of gaze. Conjunctival laceration was not observed in the slit-lamp examination. The cornea showed only few punctate epithelial defects, suggesting mild exposure keratopathy. The anterior chamber was deep in its original form. Indirect ophthalmoscopy revealed commotio retinae in the superior and temporal retina. Vitreous hemorrhage was not observed. Intraocular pressure was measured with a Schiotz tonometer and was approximately $40 \mathrm{mmHg}$. The patient's other eye was clinically unremarkable.

Cite this article as: Zandi A, Pourazizi M, Radmanesh P, Alemzadeh Ansari MH. A successful case of surgical intervention for traumatic globe luxation in a child: From light perception to full visual acuity. Ulus Travma Acil Cerrahi Derg 2019;25:202-204.

Address for correspondence: Mohammad Hasan Alemzadeh Ansari, M.D.

Department of Ophthalmology, Isfahan Eye Research Center, Isfahan University of Medical Sciences, 814889 Isfahan, Iran.

Tel: +98916 6078735 E-mail: mh.aansari@gmail.com

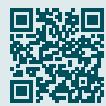

Ulus Travma Acil Cerrahi Derg 2019;25(2):202-204 DOI: 10.5505/tjtes.2018.50240 Submitted: 19.01.2018 Accepted: 19.09.2018 Online: 15.03.2019

Copyright 2019 Turkish Association of Trauma and Emergency Surgery 

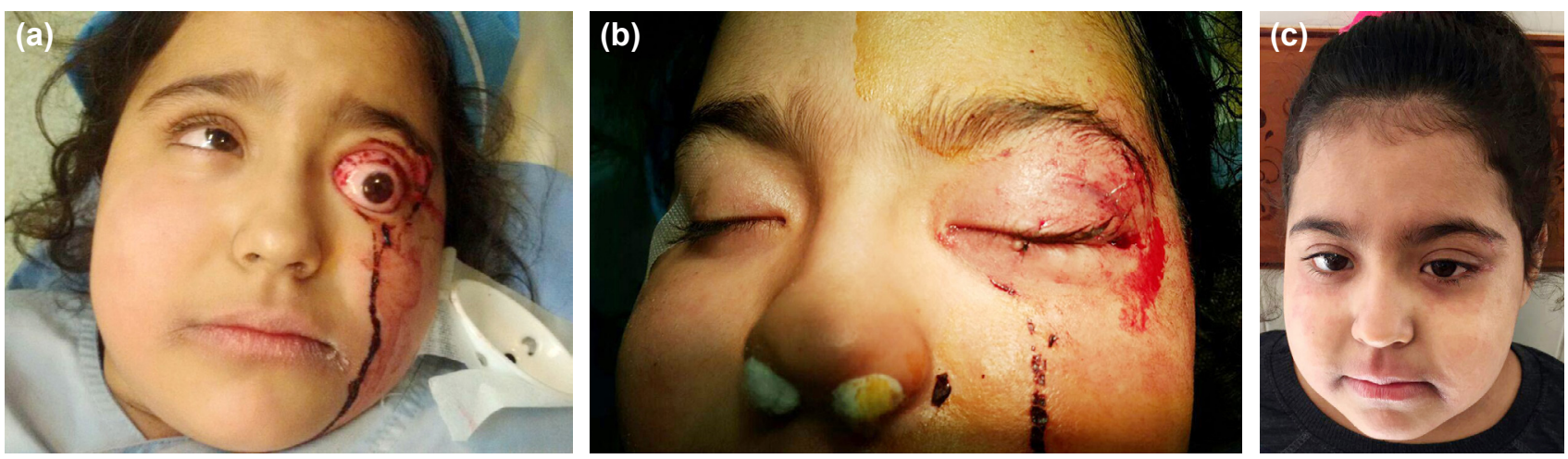

Figure 1. (a) Preoperative image of the patient showing globe luxation and eyelid laceration. (b) Post-operative image showing repair of the eyelid and temporary blepharorrhaphy. (c) Proof that the left eye movement is not limited.

Because the globe could not be repositioned back to the orbit using only digital pressure, urgent lateral canthotomy and inferior cantholysis were performed, and a massive retrobulbar hemorrhage was drained. There were no disinserted extraocular muscles following orbit exploration. Immediately afterwards, the eyeball was slowly pushed back into the orbit. Repair of the superior eyelid laceration and temporary blepharorrhaphy were then performed (Fig. Ib).

The eyeball was bandaged for 24 hours, and the temporary blepharorrhaphy was removed after I day. VA was 20/40 on the Snellen chart on the first day of the surgery. Ocular movement was restricted owing to periorbital edema. The patient received systemic Prednisolone (Nisopred ${ }^{\circledR}$; Iran hormone pharmaceutical CO., Tehran, Iran; $25 \mathrm{mg} /$ day for two days) and Syrup cephalexin (Daana Pharmaceutical CO., Tabriz, Iran; $250 \mathrm{mg}, 5 \mathrm{ml}$, every 6 hours for one week). One month into the post-trauma follow-up, VA was 20/20 on the Snellen chart, there were no limitations in eye movement in any position of the gaze (Fig. Ic), and there was no sign of optic atrophy and retinal involvement.

\section{DISCUSSION}

Traumatic globe luxation with the shape remaining intact but with significant vision loss is a rare condition that occurs more often in children and requires urgent intervention and reposition. This condition is usually related to motor vehicle accidents; however, falling off a bicycle is the most common cause of globe luxation in children. ${ }^{[4,5]}$ There are limited reports on successful surgical interventions for traumatic globe luxation in children. De Saint Sardos et al. ${ }^{[2]}$ reported clinical findings similar to those observed in our patient for traumatic globe luxation in a 6-year-old girl playing with a tube of wrapping paper.

The prognosis of vision in globe luxation depends on the status of the optic nerve. The most serious event in such a trauma is optic nerve avulsion leading to complete vision loss. This complication has reportedly occurred in $38.2 \%$ of the published cases. ${ }^{[3]}$ Moreover, if optic nerve avulsion does not occur, the final VA shows a good prognosis even with a poor vision. In one report, a 25-year-old man presented with his globe luxated out of the orbit and full optic nerve avulsion after a motor vehicle accident. In his case, the globe was repositioned into the orbit, and although the patient had no light perception, he got satisfactory cosmetic results..$^{[6]}$ In our case, the initial VA was reduced to light perception, and after one month, the VA was reported with acuity of 20/20 on the Snellen chart, indicating significant clinical improvement. In our case, the time from the incidence of the trauma to the surgical management of the condition was less than three hours, which likely contributed to the good vision outcome in the patient.

The time until surgery, the mechanism of trauma incidence, and the associated signs and symptoms may be important in determining the final outcomes of the interventions following traumatic globe luxation.

\section{Conclusion}

Because traumatic globe luxation can cause vision loss and is associated with serious complications, all physicians, particularly those working in emergency units, should be familiar with this condition and its urgent management.

Conflict of interest: None declared.

\section{REFERENCES}

1. Bajaj MS, Pushker N, Nainiwal SK, Balasubramanya R. Traumatic luxation of the globe with optic nerve avulsion. Clin Exp Ophthalmol 2003;31:362-3. [CrossRef]

2. de Saint Sardos A, Hamel P. Traumatic globe luxation in a 6-year-old girl playing with a tube of wrapping paper.J AAPOS 2007;11:406-7. [CrossRef]

3. Amaral MB, Carvalho MF, Ferreira AB, Mesquita RA. Traumatic globe luxation associated with orbital fracture in a child: a case report and literature review. J Maxillofac Oral Surg 2015;14(Suppl 1):323-30. [CrossRef]

4. Lelli GJ Jr, Demirci H, Frueh BR. Avulsion of the optic nerve with luxation of the eye after motor vehicle accident. Ophthalmic Plast Reconstr Surg 2007;23:158-60. [CrossRef]

5. Poroy C, Cibik C, Yazici B. Traumatic Globe Subluxation and Intracranial Injury Caused by Bicycle Brake Handle. Arch Trauma Res 2016;5:e33405. [CrossRef]

6. Ersan I, Adam M, Oltulu R, Zengin N, Okka M. Traumatic luxation of the globe: A 6-year follow-up. Orbit 2016;35:69-71. [CrossRef] 


\section{OLGU SUNUMU - ÖZET}

\section{Bir çocukta travmatik göz küresi luksasyonu için başarılı bir cerrahi girişim olgusu:} Işs̆ğın algılamasından tam bir görme keskinliğine

\section{Dr. Alireza Zandi, Dr. Mohsen Pourazizi, Dr. Pouriya Radmanesh, Dr. Mohammad Hasan Alemzadeh Ansari}

İsfahan Göz Araştırma Merkezi, İsfahan Tıp Bilimleri Üniversitesi, Göz Hastalıkları Anabilim Dalı, İsfahan-İran

Travmatik göz küresi luksasyonu pediyatrik acil tıpta seyrek görülen bir durumdur. Bazı olgularda travmatik göz küresi luksasyonu görme kaybına neden olabilmektedir. Bu nedenle acil servislerde kritik bir durum olduğu düşünülür. O halde özellikle acil birimlerde çalışan doktorların tümü görme kaybı gibi organı tehdit eden komplikasyonları önlemek için bu durumu ve tedavisini bilmelidir. Bu yazıda, bisikletten düştükten sonra travmaya bağlı göz küresi luksasyonu oluşan ve travmadan sonra görme keskinliği (GK) yalnızca ışığın algılanmasına kadar düşen sekiz yaşındaki bir kız çocuğu sunuldu. Bu durum acil lateral kantotomi ve inferiyor kantolizle acilen tedavi edildi. Travma sonrası birinci ayda GK Snellen ölçeğinde 20/20 olup her yöne bakışta göz hareketleri kısıtlanmamıştı.

Anahtar sözcükler: Göz küresi luksasyonu; kantotomi; pediyatrik; travma.

Ulus Travma Acil Cerrahi Derg 2019;25(2):202-204 doi: 10.5505/tjtes.20।8.50240 